\title{
QUALITY MANAGEMENT OF HIGHER EDUCATION IN THE CONTEXT OF INTEGRATION TO EUROPEAN EDUCATION AREA
}

\author{
TATIANA SALIMOVA, VASILIJ MAKOLOV, YULIA ENALEEVA \\ Mordovia N. P. Ogarev State University, Saransk, Russia
}

\section{ABSTRACT}

The article has the characteristics of multilevel quality assurance system, based on the European, national and institutional structures. The authors pay attention to quality education issues in the context of the Bologna Process under the modern conditions. The current trends and problems of quality assurance system have been defined. The experience of Mordovia State University participating in the implementation of the Standards and Guidelines for Quality Assurance in the European Higher Education Area has been presented in this article.

\section{JEL CLASSIFICATION \& KEYWORDS}

- 121 . Bologna process | Integration ㅁ. Quality a Quality management system * Quality assurance * Higher education

\section{INTRODUCTION}

Education is one of the most important elements of life quality. Many countries of the world community have developed the approach that it is education that provides the future for the development of the society. Much attention has been paid to the problem of how to improve the fully formed approaches to University quality management under the conditions of market relation.

Higher education has been affected by a number of changes in the past decade, including higher rates of participation, internationalization, the growing importance of knowledgeled economies and increased global competition. These changes have resulted in to two main European policies: the Bologna Process and the Lisbon Strategy, including the Modernization Agenda for Universities.

The Russian education system has been integrating to European education area. Key principles of Bologna Declaration are:

- Adoption of a system of easily readable and comparable degrees,

- adoption of a system essentially based on two main cycles, undergraduate and graduate,

- establishment of a system of credits,

- promotion of mobility for students and teachers, researchers and administrative staff,

- promotion of European co-operation in quality assurance with a view to developing comparable criteria and methodologies.

During recent 10 years the quality assurance of higher education is the most important priority of development and guarantee of increasing competitiveness of the higher education institutions.

\section{Qaulity asurance of education in context of Bologna} process

The development of approaches to quality education assurance in Europe are based on multiannual experience in different countries. These approaches have been reflected in the official range.

The Sorbonne Declaration, signed in 1998, provided the inspiration for the Bologna Process. This Declaration opened by stating the need to create a 'Europe of www.journals.cz/ knowledge'. Thus the Sorbonne Declaration, signed by four countries, set the stage for policy developments in the next decade.

The Bologna Declaration (1999) states as one of its central objectives the enhancement of «the international competitiveness of the European system of higher education». The Bologna Declaration was signed by 29 countries, soon to be joined by more countries for a total 47 . For over the past ten years, the Bologna Process. has mobilized the energies of students, staff members, institutional leaders and policy makers. As the process took shape many 'action lines' were added in order to achieve the following objectives: easily readable and comparable degrees, mobility, employability, quality, improved synergies between the EHEA (European Higher Education Area) and the ERA (European Research Area) through the Doctoral level, in a perspective that stresses social cohesion through access to higher education and lifelong learning.

Quality has been at the basis of the Bologna process. The Berlin Communiqué (2003) recognized the primary role of higher education institutions in monitoring quality and invited quality assurance agencies, students and higher education institutions to develop an agreed set of "standards, procedures and guidelines" on quality assurance and to explore the possibility of a "peer-review" of quality assurance agencies.

In 2005 the European Association for Quality Assurance in Higher Education (ENQA) in consultation and co-operation with the European Student' Union (ESU), the European University Association (EUA), the European association of Higher Education Institutions (EURASHE) developed the Standards and Guidelines for Quality Assurance in the European Higher Education Area [12].

The standards are in three parts covering internal quality assurance of higher education, external quality assurance of higher education and quality assurance of external quality assurance agencies. The principles of this standard are presented in table 1.

The Bergen Communiqué (2005) adopted a text of standards and guidelines for quality assurance (ESGs): one that applies to higher education institutions and two to quality assurance agencies (ENQA 2005).

The London Communiqué (2007) endorsed the proposal of setting up a European Register of Quality Assurance Agencies (EQAR) that was presented by the E4 Group.

Further development of quality issues were in the Leuven Communiqué (2009) and Budapest-Vienna Declaration on the European Higher Education Area (2010) [3].

EUA regularly carries out studies connected to the tendency revelation of Bologna Process.

The aim of the Trends 2010 report is two-fold. Firstly, to situate and analyze - from the viewpoint of higher education institutions - the implementation of the Bologna Process in the context of the much broader set of chances that have affected higher education in Europe in the past decade. Secondly, to propose an agenda for the future of both the Bologna Process and the European Higher Education Area. 
QUALITY MANAGEMENT OF HIGHER EDUCATION IN THE CONTEXT OF INTEGRATION TO EUROPEAN EDUCATION AREA

\begin{tabular}{|l|l|l|}
\hline \multicolumn{3}{|l|}{ Table 1: Principles of the Standards and Guidelines for Quality } \\
Assurance in the European Higher Education Area
\end{tabular}

The report is based on a unique longitudinal analysis of responses to two survey questionnaires to higher education institutions (821 responses) and national rectors' conferences (27 responses), which have been compared to Trends III (2005) and Trends V (2007) results. The qualitative data were supplemented with qualitative data collected through 28 site visits in 16 countries, two focus group discussions and five semi-structured interviews of regulated professional organizations [12].

The national rectors' conferences were asked to choose the three most important policy changes that have been implemented in their country, alongside the Bologna Process. The changes most frequently identified are:

- Reform of quality assurance: 18 countries,

- research policies: 15 countries,
- expansion of institutional autonomy: 12 countries,

- funding reforms: 12 countries.

The following figure 1, based on the Trends 2010 institutional questionnaires, shows the changes that have had most importance to institutional development in the past ten years.

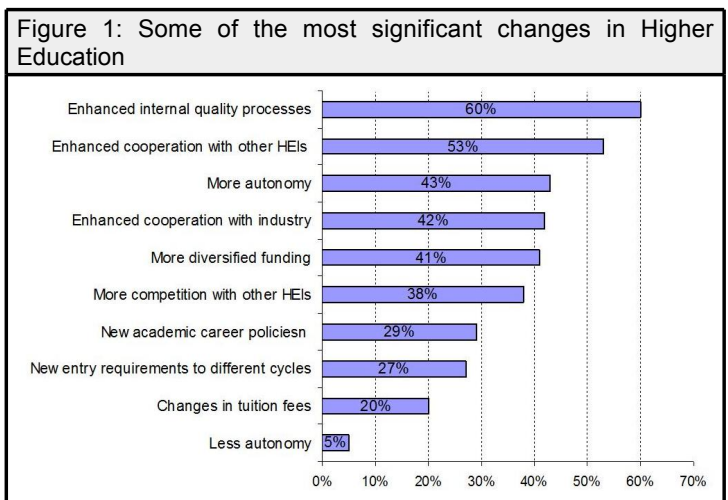

Source: http://www.eua.be/fileadmin/user_upload/files/Publications/Trends2010.pdf [12]

Over the last ten years the most significant change in Higher Education has been enhanced internal quality processes (see figure 1). Nowadays there is the multilevel system of quality assurance including European, National and Institutional levels (figure 2).

The newly established European quality assurance framework is meant as a broad structure to ensure the quality of degree awards and does not address research activities or other functions of higher education institutions. The framework respects four main principles: the primary role of institutions in managing and monitoring their quality; student participation in internal and external quality assurance processes; the political independence of quality assurance agencies; and the diversity of national quality assurance procedures.

Integration of Russian higher education system to European education area

Onrush of scientific-technological progress, integration of Russia into the world community, development of new information technologies require more requirements to the

Figure 2: The structure of quality assurance system

\section{European quality assurance system}

(ESG standards and EQAR): increasing students' involvement; good competence

National level of quality assurance:

procedure accumulation; domination of program quality assurance; accreditation distribution

Institutional level of quality assurance: development of culture quality; implementation of quality management system; employment of self-assessment tool 
higher education system. Education has become a priority area of social and economic development. On the basis of quality management, problems in the education are topical.

In Russia education quality is a core for specialists in the field of quality management. But until now there has been no single approach to the definition of the notion of "education quality", that can be explained by the complexity of the category of "quality", diversity of the interpretation of the notion "education", its integral parts possessing the quality; difference in perception the education quality by the concerned parties (such as State, employers, students, University, etc.). Table 2 presents some of the definitions of the examined notion.

\begin{tabular}{|l|l|}
\hline Table 2: Approaches to content of "education quality" definition \\
\hline Author & \multicolumn{1}{|c|}{ Definition of the "education quality" notion } \\
\hline Polonskij V.M. [7] & $\begin{array}{l}\text { Certain level of knowledge and skills, mental, } \\
\text { physical and moral development reached by } \\
\text { school alumni in accordance with the } \\
\text { planned goals of education process. }\end{array}$ \\
\hline $\begin{array}{l}\text { Shishov S. E., } \\
\text { Kolnej V.A. [11] }\end{array}$ & $\begin{array}{l}\text { Social category defining the condition and } \\
\text { effectiveness of educational process in } \\
\text { society, its correspondence to the needs of } \\
\text { society in formation of civil, domestic and } \\
\text { professional competence of a person. }\end{array}$ \\
\hline $\begin{array}{l}\text { Potashnik M.M., } \\
\text { Yamburg E.A., } \\
\text { Matros D.Sh., } \\
\text { Myslev A.I., etc. [8] }\end{array}$ & $\begin{array}{l}\text { Correlation of the goal and result, the way to } \\
\text { reach the goal when that the goal (result) are } \\
\text { operationally set and expected in the field of } \\
\text { potential development of a student. }\end{array}$ \\
\hline Pushkov N.P. [9] & $\begin{array}{l}\text { The complex of education characteristics, } \\
\text { which regulates its abilities to meet the } \\
\text { demands of the society in the field of } \\
\text { specialists' vocational training, who have all } \\
\text { necessary personal and professional } \\
\text { qualities. }\end{array}$ \\
\hline Doroboluk T.D. [4] & $\begin{array}{l}\text { The level of education correspondence (i.e. } \\
\text { the accumulation of knowledge and skills by } \\
\text { a person within a certain period of time) to } \\
\text { demands changing in time. }\end{array}$ \\
\hline Source: Author & \\
\hline
\end{tabular}

The definitions given in Table 2 are not limited to the existing views on the content of education quality. However, this diversity can be combined into the following groups:

1. Education quality as an ultimate assessment. In this meaning education quality is the synonym of superiority, perfection; it is an utter sign of accordance to certain demands. As the perfection is an abstract and subjective category its perception can vary significantly. That is why such approach has not been widespread in recent years.

2. Education quality as the unity of characteristics. In this meaning the education quality is a derivative of any quantitatively measured parameter of an education service. But this approach is rather narrow, since it does not reflect the significance of the education service to its customer.

3. Education quality as the answer to its purpose. According to this interpretation the application of the quality to the mentioned field represents the ability of education to implement its social functions.

4. Education quality as the accordance to its standards. This approach is traditional and it has been in use in the field of education for a long time.

5. Education quality as the degree of customers' requirements satisfaction, as well as the other parties concerned. Nowadays, this approach is particular popular and it is explainable. This definition is similar to the one of MS ISO 9000:2005. Both of these standards define quality as the degree where the unity of object characteristics meets the demands [5]. Based on such an interpretation of quality the most substantial things is the approach elaborated by Quality Research Center in the field of vocational training, that considers the quality of University education as balanced correspondence of higher education (as the result, process, and system) to diverse demands, goals, needs and standards [10].

There are the following most important characteristics of the education quality.

- The quality of values, goals and standards define that level that measures the quality of educational services, training and education in general, and which shows the demands of the various customers groups.

- The quality of conditions is characterized by the level of material and technical basis, social infrastructure of University, the level of professionalism of its teaching staff, students intellectual potential; space-time infrastructure, etc.

- The quality of educational process can be divided into the quality of its content and educational technologies. The content of education quality shows the level of academic and methodological basis; the content of educational programs of school courses.

- In our opinion the quality of the results of the education output is shown in the definition given by E. M. Korotkov. According to it "the education quality is a complex of characteristics of professional mentality that defines the ability to conduct professional activities in accordance with demands of contemporary economy" [6].

Thus, education quality management considers management with all its constituents. It is the activity aimed at meeting the quality demands, made by consumers and other parties concerned. The major functions of the quality management are planning, assurance, motivation, control, and improvement.

Quality planning at University is the process of goals setting in the field of the education quality, determination of necessary operational processes and corresponding resources in order to reach the set goals.

Quality assurance is a type of activity directed to the establishment of confidence that demands in conditions, process and results quality will be met; the activity closely related to the formation of necessary organization mechanism of education quality management.

Quality motivation is the process directed to the increase of a higher education institution personnel interest in assurance and improvement of quality.

Quality control is the activity directed to the confirmation of the accordance of conditions, content, and results quality to demands.

Quality improvement is the process directed to the increase in a higher education institution ability to meet the demands to education quality. This function shows the implementation of innovative educational activity.

However, the achievement of these functions is possible only on integrative basis. That is to manage the quality at University is necessary from the point of quality management system. The necessity to implement such system is determined by several circumstances among which there is internationalization of education and entry of Russia into joined European education area. Russia signed the Bologna Declaration, which emphasizes the necessity of further development of the system of quality assurance 
for Universities both on national and European levels. In the communiqué of the Conference of Ministers responsible for higher education "Formation of All-European Area of Higher Education" that took place in Berlin in September 19, 2003 it is emphasized that according to the principle of institutional autonomy the responsibly for education quality assurance is taken by every University. Reasoning from this fact quality assurance is developing in the context of European tendencies in the education area.

The ESG were translated into Russian for the purposes of widespread familiarization by the HEI community, and special seminars are held to acquaint the heads of HEls as well as experts involved in expert reviews of $\mathrm{HEl}$ activities, with the ESG. The document was recommended by the Accreditation Board meeting of 05.04.2007 for establishing $\mathrm{HEl}$ internal quality assurance systems.

One of the criteria for the accreditation of an HEI is the efficiency of the internal quality assurance system.

On the basis of the ESG, a standard model for internal quality assurance has been developed, and recommended for widespread application.

Federal Inspection competition in the field of education and science created an inter-academic centre for supporting the implementation of standard model of quality management system in the field of higher education, based on St. Petersburg State Electrotechnical University. In Russia the network of the regional centers has been created. The network is oriented on the improvement of mechanisms of quality assurance in the higher education.

Correspondence to the ESG is defined as follows [1]:

- Annual monitoring of the quality of education of student and graduates is a condition of accreditation; educational management departments operate in each $\mathrm{HEI}$, and in recent years in many HEls such centers for the management and monitoring of the quality of education have been created,

- stimulation of the development of a culture of quality in HEls - this is the goal with which the Federal Service for Supervision in Education and Research annually holds a competition among internal quality assurance systems. The number of HEls participating in this competition has been growing every year, there has also been an increase in the number of HEls which have chosen to certify their systems according to ISO 9000 standards, EFQM and others,

- all Russian HEls annually submit reports on the main areas of their activity to the Central State Accreditation Database. The Central database of state accreditation annually collects information about the availability and effectiveness of an HEI internal quality assurance system. The analysis of collected information reveals that $920 \mathrm{HEls}$ have established an internal quality assurance system with $661 \mathrm{HEls}$, where the operation of internal quality assurance system covers the whole institution. 279 HEls have established an internal quality assurance system in separate subdivisions (departments) and 611 institutions have developed quality assurance systems for separate processes (managerial, educational, and others) [2].

In order to establish an effective quality assurance system a HEI has to formulate its mission, develop a quality assurance policy, set goals and objectives, conduct regular monitoring and updating of delivered educational programs. All these processes should be discussed and coordinated with all relevant stakeholders. $817 \mathrm{HEls}$ have evidence (reports, records) of using feedback from students and other stakeholders (employers, state, public, etc.) when developing their quality assurance policy.

In recent years amendments in the legislation were adopted, which put the Russian system of quality assurance of $\mathrm{HE}$ in line with the European system: the former procedure of attestation was integrated with accreditation.

Thus, the quality assurance system in education comprises two procedures [2]:

- Licensing of educational activity - an authorizing procedure allowing to offer educational programs,

- state accreditation of educational institutions, which involves an external evaluation of the content and quality of education and training and their compliance with the federal state educational standards. It also evaluates indicators of a HEls performance, which is necessary for the determination of its status: type (a higher education institution) and kind (university/academy/institute) The state accreditation procedure is conducted on the grounds of application from an institution and is compulsory for all previously accredited higher educational institutions regardless of their legal organizational form (state, municipal, private) and location. The normative and legal basis of the state accreditation procedure containing requirements, indicators and criteria of accreditation, is formally approved and publicly accessible. It is uniform for all higher educational institutions. Accreditation in Russia is national and institutional (accreditation of the whole institution), it also includes program accreditation in accredited HEls.

By law state accreditation is conducted by the federal state executive body responsible for control and supervision in the sphere of education - the Federal Service of Supervision in Education and Science (Rosobnadzor). The accreditation decision is made by a collective body - Accreditation Board. Performance of certain tasks and evaluation procedures is delegated to specialized state institutions.

The concept of an "expert" - "a peer review team member" was introduced into the law as well as the requirement for training and certification of experts. For the purpose of external evaluation of HEls external review panels are set up. These panels go to the sites and conduct evaluation on the basis of the HEl's self-evaluation. Since 2006 experts participating in peer review teams, have been united in the Guild of Experts in the Sphere of Professional Education.

Thus, the quality assurance system in Russia has been established. It is regularly updated and enhanced to be in line with the Standards and Guidelines for Quality Assurance in European Higher Education Area.

Experience of realization of Bologna Process fundamentals at N.P. Ogarev Mordovia State University

Mordovia State University is the largest University of Povolzhie region and one of the largest University of Russia. It was based in 1931. Today the University includes 7 education institutes and 13 faculties that include 151 chairs. The University has got two branches. Mordovia University has facilities in Saransk, Republic of Mordovia, one of the Russian regions, which is located in the central part of Russia. The total number of students is over 24 thousand people and the academic staff includes 1600 members.

At Mordivia University, students can earn degrees in different subject areas: Education, Technology, Art, Medicine, Agronomical studies, Biotechnology, Economics, Law, Linguistics, etc. The University realizes 48 bachelor's 
degree, 21 master's degree programs and 82 specialist's programs.

In 2010 the University was conferred the status of National Research University by the official decision of the Russian Government.

Mordovia State University has always paid great attention to increase of education quality, formation of quality control systems at faculties and departments, development of innovative approaches to the organization of the educational process. At the end of 2004 at the University it was decided to launch the quality management system according to the requirements of the international standard ISO 9001.

To coordinate the works in the field of elaboration of intra-university quality systems at Russian Universities, the Education Activity Quality Board and the department of quality management of education activity were organized. On the basis of Economic Department the Quality Management Centre providing informational and consulting services in the field of quality management was opened.

General management of the program of quality management system formation is conducted by Rector of the University. Pro-rector who is in charge of academics is also the representative of the University authorities in quality and coordinates the implementation of all the activities of sub-systems and elements of quality management system of the University development.

In order to organize and manage the quality management system, the representative in quality has been appointed with the following responsibilities:

- Setting up, implementing, evaluating and improving the quality management system, including: quality policy, quality handbook, short-term and long-term quality planning,

- identifying and implementing quality management standards to ensure quality care to stakeholders,

- reviewing and evaluating the effectiveness of the quality management standards and setting up improvement plans if necessary,

- complying evaluations, summarizing the quality management findings and indicating points for improvement,

- archivizing quality documents, policies, analyses, evaluations and providing this information for all interested parties.

The Education Activity Quality Board is a collective senior body that coordinates the work of subdivisions in the sphere of quality management system, aimed at increase of the training quality of University specialists, constant improvement of the educational process. The Board conducts the development of the policy and strategy of quality management of educational process with the consideration of the education process specification. The department of education quality management works out the documents of quality management system, conducts annual self-evaluation of the Departments and Faculties, organizes surveys for various groups of the University consumers regarding the questions of the education quality.

Training the personnel in the fundamentals of the theory and practice of quality management is one of the key points in the process of formation and improvement of quality management system in any company. For that reason in 2006 the University launched the program "Quality Management in the Field of Higher Professional Education" to promote managers' skills. The program was developed by the group of Faculties from Quality Management Chair alongside with the authorities of Economic Department, College of Physics and Chemistry, and the staff of the department of education quality management. The program is aimed at: study the modern models of quality assurance in the field of University staff training; research of major statements of the University quality management system; necessity and possibility of implementation of the process approach in management; the content of quality management system documents; methods and tools of quality management at the University. During the training process it reveals the questions about monitoring and diagnostics of students' knowledge quality under the conditions of evaluation rating system of students' academic activities; teachers motivation problems according to quality management system and etc.

By the results of the participation in "Specialists Training Quality Assurance Systems" Federal Inspection competition in the field of education and science that took place in 2006, Mordovia State University was declared as a laureate.

Mordovia State University is a permanent participant and a winner of "The best goods of Mordovia" region competition and "The best 100 goods of Russia" All-Russia ProgramCompetition

Mordovia Regional Division of Quality Problems Academy has been established based on Mordovia University. This division researches, organizes international, All-Russian and region conferences, collaborates with business companies.

In the University development program for 2011-2015 there is a direction of improvement of quality education and competitiveness of the University graduates that includes the following:

- Development of quality management system, based on good quality assurance models, requirements of the international standards ISO 9000 and ENQA,

- improvement of educational programs structure and content within the multilevel system of professional education,

- increasing the quality of teaching materials, facilities, stuffing and information service for educational process,

- active implementation of innovative methods of teaching and evaluation techniques of students' knowledge,

- mutually beneficial cooperation with Russian and international education and research institutions and assurance of high level of business partner confidence in the University,

- development of the internal academic environment, oriented on creative personal fulfillment.

In 2008 Mordovia State University won the competition in forming the Regional Centre for supporting the implementation of standard model of quality management system in the field of higher education. This centre was created for encouragement and development of quality management systems in all the higher education institutions in Povolzhie Federal district. Nowadays in Russia there are 8 Regional Centres, every federal district and Moscow have the Regional Centre.

The main tasks of the Regional Centre are methodical and consulting supporting of development of quality management systems in the higher educational institutions and carrying out the personnel training programs in quality management field. 
Mordovia State University has taken part in the experiment in the testing of standard model of quality management system in the field of higher education. Within this project the university has been assessed according to the Standards and Guidelines for Quality Assurance in the European Higher Education Area (which is a part for internal quality assurance).

The assessment of quality management system of Mordovia University has been fulfilled by experts of the Federal Inspection of Monitoring in the Field of Education and Science. The results of assessment are presented in Table 3.

\begin{tabular}{|c|c|c|}
\hline \multicolumn{3}{|c|}{$\begin{array}{l}\text { Table 3: Results of assessment of quality management system at } \\
\text { Mordovia State University according to the Standards and } \\
\text { Guidelines for Quality Assurance in the European Higher } \\
\text { Education Area }\end{array}$} \\
\hline Section ENQA & $\begin{array}{l}\text { Maximum } \\
\text { score in } \\
\text { points }\end{array}$ & $\begin{array}{l}\text { The actual } \\
\text { score in } \\
\text { points }\end{array}$ \\
\hline $\begin{array}{l}\text { 1. Policy and procedures for quality } \\
\text { assurance }\end{array}$ & 24 & 20 \\
\hline $\begin{array}{l}\text { 2. Approval, monitoring and periodic } \\
\text { review of programs and awards }\end{array}$ & 24 & 20 \\
\hline 3. Assessment of students & 21 & 17 \\
\hline 4. Quality assurance of teaching staff & 18 & 14 \\
\hline $\begin{array}{l}\text { 5. Learning resources and student } \\
\text { support }\end{array}$ & 12 & 10 \\
\hline 6. Information systems & 24 & 22 \\
\hline 7. Public information & 12 & 10 \\
\hline Total & \begin{tabular}{|l|}
135 \\
\end{tabular} & 113 \\
\hline
\end{tabular}

The assessment has highlighted that Mordovia University developed quality management system and it generally meets the criteria of ENQA. The main document of quality management system - Strategic vision and quality policy has been acknowledged as one of the best in Russia and included into the collection "The best practice of elaboration of quality management systems at Russian education institutions". All experts noticed that the university had good developed processes, especially process of curriculum development, researches and outclass activities. However, we consider, that Mordovia University needs to develop its information systems and learning resources, as well as improvement of assessment students' techniques and assurance of teaching staff.

\section{Conclusion}

Thus, development of quality assurance mechanisms is to be continued on different levels: European, national and institutional. In a short-term period improvement of the European quality assurance system of education will be based on the follow priorities: lifelong learning; partnership and forming of the European knowledge area. Realization of the priorities on the national level should be carried out according to specifics of the national education system and accumulated experience. Higher education institutions are primarily responsible for quality assurance.

\section{REFERENCES}

1. Bologna Process. The Russian Federation National Reports 2005-2007. http://www.bologna.ntf.ru/DswMedia/nr2005-2007_engl. pdf

2. Bologna Process. The Russian Federation National Reports 2007-2009. http://www.bologna.ntf.ru/DswMedia/nr2007-2009_engl. pdf
3. Budapest-Vienna Declaration on the European Higher Education Area, March 12, 2010. http://www.enqa.eu/files/Budapest-Vienna_ Declaration.pdf

4. Doroboluk T.D. Special Features of Quality Management System Formation in the Field of Education // Quality Management: Methods, Social and Economic Problems. 1st International Academic Conference. Tambov, May 11-12, 2005. Tambov State Technical University. 2005.

5. ISO 9000:2005 Quality management systems - Fundamentals and vocabulary. ISO, 2005.

6. Korotkov E.M. Quality of Education, Formation, Facts, Evaluation and Management. Moscow, 2002.

7. Polonskij V.M. Dictionary of Notions an Terms in Russian Educatinal Law. Moscow, 1995.

8. Potashnik M.M., Yamburg E.A., Matros D.Sh., Myslev A.I., etc. Education Quality Management / Potashnik M.M.ed. - Moscow, Russian Pedagogical Society, 2004.

9. Pushkov N.P. System of Quality assurance of University Education // Quality Management: Methods, Social and Economic Problems. 1st International Academic Conference. Tambov, May 11-12, 2005/ Tambov State Technical University. 2005.

10. Selezneva N.A. Quality of Higher Education as the Object of System approach. Moscow. Research Centre of Quality Problems in the field of Specialists, 2001.

11. Shishov S. E., Kolnej V.A. Quality Monitoring of Secondary Education, Moscow, 1998.

12. Trends 2010: a decade of change in European Higher Education. http://www.eua.be/fileadmin/user_upload/files/Publications/Trends_ 2010.pdf 